\title{
TOKSISITAS EKSTRAK BIJI Barringtonia asiatica (LECYTHIDACEAE) TERHADAP MENCIT PUTIH (Mus musculus Strain DDY)
}

\section{THE TOXICITY OF Barringtonia asiatica (LECYTHIDACEAE) SEED EXTRACT TO WHITE MICE (Mus musculus Strain DDY)}

\author{
Wahyu Daradjat Natawigena, Danar Dono, Ivan Febriana \\ Departemen Hama dan Penyakit Tumbuhan, Fakultas Pertanian \\ Universitas Padjadjaran, Bandung, Jl. Raya Bandung Sumedang KM.21, Jawa Barat \\ Korespondensi : w.daradjat@unpad.ac.id
}

Diterima 19 November 2018/ Disetujui 11 Desember 2018

\begin{abstract}
ABSTRAK
Salah satu tanaman yang berpotensi sebagai pestisida nabati adalah Bitung (Baringtonia asiatica) yang teruji mengandung terpenoid dan saponin. Penelitian ini bertujuan untuk mengetahui toksisitas ekstrak kasar (B. asiatica) terhadap mencit putih (Mus musculus) dan potensinya sebagai rodentisida nabati. Penelitian menggunakan metode eksperimen dengan rancangan percobaan Rancangan Acak Lengkap (RAL). Pengujian toksisitas B. asiatica terhadap mencit dilakukan secara oral dengan menghitung $\mathrm{LD}_{50}$ menggunakan metode analisis probit. Pengamatan perilaku mencit yang keracunan ekstrak B.asiatica dilakukan dengan menggunakan metode Wagner \& Wolff. Pengamatan perubahan fisiologis mencit yang teracuni ekstrak metanol biji $B$. asiatica dilakukan dengan menggunakan kandang metabolisme (Nalgane Metabolic Cages). Hasil penelitian menunjukkan bahwa ekstrak biji B. asiatica bersifat toksik terhadap mencit putih ( $M$. musculus) dengan nilai $\mathrm{LD}_{50}=2022 \mathrm{ppm}$ atau $0,2022 \%$ dan digolongkan ke dalam skala toksistas 3 yaitu senyawa dengan toksisitas sedang. Ekstrak $B$. asiatica mempengaruhi sistem syaraf pusat dan dapat mengakibatkan perubahan pada organ detoksifikasi. Ekstrak biji $B$. asiatica dapat meningkatkan produksi urin, menurunkan laju konsumsi dan produksi feses, dan menurunkan pertumbuhan bobot mencit. Dengan demikian ekstrak biji $B$. asiatica berpotensi untuk dikembangkan sebagai bahan aktif rodentisida.
\end{abstract}

Kata kunci: Barringtonia, ekstrak, fisiologis, mencit, toksisitas $\mathrm{LD}_{50}$

\section{ABSTRACT}

One of the plants that potentially as botanical pesticides is the Bitung (Baringtonia asiatica) which is tested contained of terpenoid and saponin. This research aimed was to determine the toxicity of crude extracts ( $B$. asiatica) to white mice (Mus musculus) and their potential as botanical rodenticides. The research used an experimental method with complete randomized design. $B$. asiatica toxicity testing in mice was carried out orally by calculating $\mathrm{LD}_{50}$ using the probit analysis method. Observation of the behavior of B.asiatica extract poisoning mice was carried out using the Wagner \& Wolff method. The physiological experience of mice which were poisoned by the methanol extract of $B$. asiatica seeds was carried out using a cage (Nalgane Metabolic Cages). The results showed that $B$. asiatica seed extract was

Cite this as: Natawigena, W. D. Dono, D \& Febrian, I. (2018). Toksisitas ekstrak biji Barringtonia asiatica (Lecythidaceae) terhadap mencit putih (Mus musculus Strain DDY). Jurnal Agro, 5(2), 76-85. https://doi.org/10.15575/3589 
toxic to white mice (M. musculus) with $\mathrm{LD}_{50}=2022 \mathrm{ppm}$ or $0.2022 \%$ and classified into toxicity scale 3, namely compounds with moderate toxicity. B. asiatica extract affects the central nervous system and in turn detoxifying organs. B. asiatica seed extract can increase urin production, reduce the rate of consumption and facial production, and reduce the weight level of mice. Therefore that $B$. asiatica seed extract potentially to be developed as an active ingredients of rodenticides.

Keywords: Barringtonia, extracts, physiology, mice, toxicity $L_{50}$

\section{PENDAHULUAN}

Sampai saat ini pengembangan rodentisida yang ramah lingkungan dengan memanfaatan pestisida nabati masih belum banyak dilakukan. Pestisida nabati sebagai pestisida yang bahan dasarnya berasal dari tumbuhan. Selain itu pestisida nabati merupakan alternatif lain dalam mengendalikan OPT agar petani tidak tergantung pada pestisida sintetis (Kardinan, 2011). Salah satu pestisida nabati yang memiliki potensi sebagai rodentisida adalah tanaman Bitung (Baringtonia asiatica). Senyawa bioaktif yang terkandung di dalam biji $B$. asiatica adalah senyawa golongan triterpenoid saponin (Komansilan \& Suriani, 2016).

Uji fitokimia menunjukkan adanya terpenoid dan saponin dalam ekstrak kasar Biji B. Asiatica (Montes et al., 2017). Saponin merupakan racun perut dan dapat menghambat aktivitas makan serangga (Kardinan et al., 2011). Ekstrak biji B. asiatica diketahui efektif dalam mengendalikan larva nyamuk Demam Berdarah Dengue (DBD) nyamuk Aedes aegypti (Komansilan \& Suriani, 2016). Nelayan di pulau Samoa dan kepulauan Pasifik menggunakan biji $B$. asiatica sebagai racun untuk menangkap ikan (Febritami et al., 2018; Ravikumar et al., 2015). Fraksi butanol biji B. asiatica bersifat sitotoksik terhadap larva udang air tawar (Rumampuk et al., 2010). Ekstrak pekat metanol dari daun, buah, biji, dan akar serta beberapa fraksinya (gasolin, diklorometana, etil asetat dan butanol) memperlihatkan aktivitas anti bakteri berspektrum luas (Govindam et al., 2011). Zat yang berperan sebagai anti bakteri adalah triterpenoid, alkaloid, flavanoid, saponin, sterol dan tannin (Rumampuk et al., 2010). B. asiatica diketahui memiliki berbagai senyawa kimia yang berpotensi untuk dikembangkan sebagai insektisida (Dono et al., 2012). Namun toksisitas bahan racun $B$. asiatica terhadap hama golongan rodentia belum diketahui dan belum terungkap, selain itu keamanannya terhadap manusia juga belum diketahui. Hal ini dianggap sangat penting untuk perkembangan riset selanjutnya baik mengenai ilmu dasar maupun ilmu terapan. Oleh karena itu studi pemanfaatan $B$. asiatica dan racunnya tersebut penting dilakukan dari berbagai aspek.

\section{BAHAN DAN METODE}

Penelitian dilakukan di Laboratorium Vertebrata Hama Sub Lab. Hama Fakultas Pertanian UNPAD. Penelitian ini dilakukan dengan menggunakan metode eksperimen dengan rancangan percobaan Rancangan Acak Lengkap (RAL). Pengujian toksisitas $B$. asiatika terhadap mencit (Mus musculus) menggunakan metode analisis probit. Uji toksisitas dilakukan secara oral dengan 
menghitung $\mathrm{LD}_{50}$. Data mortalitas dianalisis dengan analisis probit (Finney, 1974). Pengamatan perilaku mencit yang keracunan ekstrak B. asiatica dilakukan dengan menggunakan metode Wagner \& Wolff (Natawigena \& Soedigdo, 1998). Metode ini dapat menghubungkan antara gejala keracunan dengan perkiraan efek faali pada mencit akibat pemberian ekstrak B.asiatica. Pengamatan perilaku mencit dilakukan segera setelah pemberian ekstrak metanol biji $B$. asiatica sampai tanda-tanda klinis hilang. Pengamatan perubahan fisiologis mencit yang keracunan ekstrak metanol biji $B$. asiatica dilakukan dengan menggunakan kandang metabolisme (Nalgane Metabolic Cages). Pengamatan fisiologis hewan dilakukan terhadap : pertambahan berat badan, konsumsi makanan, produksi faeces dan produksi urin.

Crude ekstrak biji $B$. asiatica disiapkan dengan cara mengeringkan biji $B$. asiatica, kemudian biji yang sudah kering dihancurkan dan disaring. Serbuk hasil saringan diekstraksi dengan pelarut organik metanol. Hasil penyaringan diuapkan dengan Vacuum rotary evaporator pada suhu $50^{\circ} \mathrm{C}$ dan penghampaan pada tekanan 580-600 mmHg. Sampai diperoleh ekstrak metanol pekat (crude ekstract) dari biji $B$. asiatica. Hewan uji yang digunakan adalah mencit putih ( $M$. musculus) berjenis kelamin jantan dengan umur dan berat yang relatif sama dengan kisaran kurang dari $10 \%$. Sebelum penelitian dilaksanakan, semua hewan uji diadaptasikan dulu di laboratorium selama satu minggu.

\section{HASIL DAN PEMBAHASAN}

Hasil Pengujian toksisitas crude ekstrak biji B. asiatika terhadap mortalitas mencit (Mus musculus)

Mortalitas mencit putih (Mus musculus) setelah diberi crude ekstrak biji $B$. asiatica dengan cara dicekok (gavage) melalui oral menggunakan alat sonde pada beberapa taraf dosis. Pada tahap ini sejumlah mencit dibagi secara acak ke dalam lima kelompok, setiap kelompok terdiri dari sepuluh ekor mencit. Mortalitas mencit putih dengan persentase kematian terendah (20\%) diperoleh dengan pemberian dosis crude ekstrak biji B. asiatica sebanyak 200 ppm. Mortalitas mencit putih dengan persentase kematian tertinggi (100\%) diperoleh dengan pemberian dosis crude ekstrak biji $B$. asiatica sebanyak $4000 \mathrm{ppm}$. Hal ini mengidikasikan bahwa $L_{50}$ berada di antara dosis 200 ppm dan 4000 ppm. Selanjutnya dibuat dosis diantara nilai tersebut dengan menggunakan rumus interval geometris sehingga diperoleh dosis 200 ppm; 442,95 ppm; 894,43 ppm; 1891 ppm dan 4000 ppm. Pada tahap ini sejumlah mencit dibagi lagi secara acak ke dalam lima kelompok, setiap kelompok terdiri dari sepuluh ekor mencit. Mortalitas mencit setelah diberi crude ekstrak B.asiatica dengan lima tingkat seri dosis secara interval tertera pada Gambar 1.

Mortalitas mencit sudah dapat terlihat satu jam setelah perlakuan yaitu pada dosis 4000 ppm yang mengakibatkan kematian 10 $\%$. Pada dua jam setelah perlakuan mortalitas mengalami peningkatan pada semua taraf dosis mulai dari 200 ppm sampai 4000 ppm dengan mortalitas yang berbeda sesuai taraf dosis yang diberikan. 


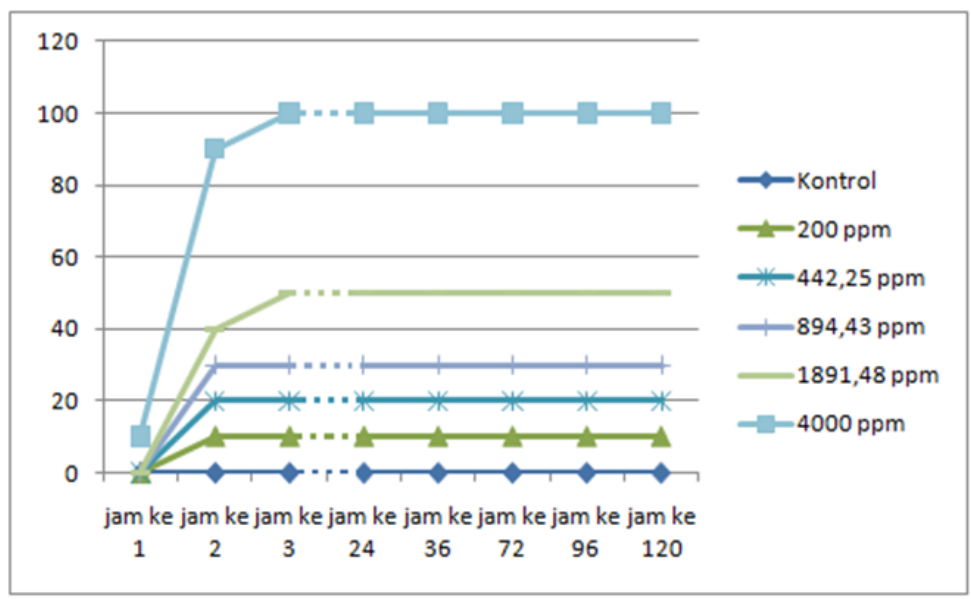

Gambar 1 Mortalitas mencit putih (Mus musculus) setelah perlakuan beberapa tingkat dosis crude ekstrak biji B.asiatica

Peningkatan mortalitas juga terjadi tiga jam setelah perlakuan yaitu pada dosis $1.891,48$ ppm dan 4.000 ppm dengan mortalitas $50 \%$ dan $100 \%$ pada masing-masing perlakuan.
Namun mortalitas mencit tidak mengalami peningkatan pada jam berikutnya setelah perlakuan.

Tabel 1. Tingkatan dosis crude ekstrak B. asiatica terhadap kematian mencit melalui rute pemberian oral

\begin{tabular}{ccccccc}
\hline $\begin{array}{c}\text { Dosis crude } \\
\text { ekstrak } \\
\text { B.aciatica } \\
\text { (mg/Kg BB) }\end{array}$ & $\begin{array}{c}\text { Log } \\
\text { Dosis }\end{array}$ & N & Hidup & Mati & $\begin{array}{c}\text { Persentase } \\
\text { kematian } \\
\text { (\%) }\end{array}$ & $\begin{array}{c}\text { Probit } \\
\text { persentase } \\
\text { kematian }\end{array}$ \\
\hline Kontrol & - & 10 & 10 & 0 & 0 & - \\
200,00 & 2.301 & 10 & 9 & 1 & 10 & 3.72 \\
442,25 & 2.645 & 10 & 8 & 2 & 20 & 4.16 \\
894,43 & 2.951 & 10 & 7 & 3 & 30 & 4.48 \\
$1.891,48$ & 3.276 & 10 & 5 & 5 & 50 & 5 \\
$4.000,00$ & - & 10 & 0 & 10 & 100 & - \\
\hline
\end{tabular}

Hal ini disebabkan oleh sifat racun dari ekstrak metanol biji $B$. asiatica yang bersifat akut. Menurut Dono et al. (2012) B. asiatica diketahui memiliki senyawa aktif yang disebut saponin. B. asiatica selain memiliki karakter toksik juga memiliki aktivitas antifeedant. Salah satu senyawa paling beracun dari ekstrak biji $B$. asiatica adalah ranunkosida III. Perlakuan pada taraf kontrol tidak menunjukan adanya mortalitas baik hari pertama setelah perlakuan sampai hari kelima setelah perlakuan. Hasil pengujian $\mathrm{LD}_{50}$ Ekstrak Metanol Biji $B$. asiatica, dari mulai menit ke 60 sampai menit ke 120, tertera pada Tabel 1. Dengan menggunakan metode Finney serta perhitungan regresi linear sederhana maka didapatkan nilai $\mathrm{LD}_{50}(120$ menit) ekstrak kasar $B$. asiatica terhadap mencit adalah 2022 ppm. 
Pengaruh crude ekstrak biji B. asiatica terhadap perilaku mencit putih ( $M$. musculus)

Mencit yang diberi dosis ekstrak metanol biji $B$. asiatica sebanyak $616,96 \mathrm{ppm}\left(\mathrm{LD}_{25}\right)$, $1514,145 \mathrm{ppm}\left(\mathrm{LD}_{50}\right)$ dan $3714,6 \mathrm{ppm}\left(\mathrm{LD}_{75}\right)$, memperlihatkan gejala-gejala keracunan yang hampir sama. Perbedaannya hanya terletak pada waktu timbulnya gejala keracunan. Pada $\mathrm{LD}_{25}$ gejala keracunan tampak pada waktu 1 jam 45 menit setelah perlakuan lebih lama dibandingkan $\mathrm{LD}_{50}$ yang terlihat pada 1 jam setelah perlakuan dan $\mathrm{LD}_{75}$ yang terlihat pada waktu 30 menit setelah perlakuan. Gejala keracunan yang timbul pada mulanya ditandai dengan penurunan aktivitas motorik seperti tikus lebih banyak diam dari pada bergerak. Lalu dalam beberapa saat ukuran pupil mata pada mencit mengecil, terjadi gerakan berjalan yang sempoyongan lalu lama kelamaan mengalami gejala kelumpuhan kaki seperti gerakan berjalan menyusuri lantai. Pada keadaan demikian mencit mengalami penurunan rasa ingin tahu, kehilangan refleks berdiri ketika dilempar ke atas dan ekor mengangkat ke atas. Selain itu terjadi kejang-kejang ringan dan tidak memberikan reaksi apabila ekor mencit itu dijepit (tes Hafner positif), lalu terjadi kejang-kejang lagi dan akhirnya mengalami kejang seluruh badan lalu akhirnya mati. Hal ini sejalan dengan Natawigena \& Soedigdo (1998) bahwa gejala racun syaraf adalah dapat menyebabkan perilaku kejang kejang sebelum kematiannya.

Tabel 2. Hubungan antara gejala keracunan dengan perkiraan efek faali pada mencit akibat pemberian ekstrak B.asiatica

\begin{tabular}{|c|c|c|}
\hline $\begin{array}{c}\text { Gejala keracunan } \\
\text { Akibat pemberian } \\
\text { ekstrak kasar B.asiatica } \\
\text { (Hasil skrining) }\end{array}$ & $\begin{array}{l}\text { Perkiraan efek faali pada tikus } \\
\text { (Menurut Wagner \& Wolff) }\end{array}$ & $\begin{array}{c}\text { Nilai menurut } \\
\text { Wagner \& } \\
\text { Wolff }\end{array}$ \\
\hline $\begin{array}{l}\text { Penurunan aktivitas } \\
\text { motoric }\end{array}$ & $\begin{array}{l}\text { Menghambat sistem syaraf pusat, } \\
\text { Simpatolitik, relaksasi otot }\end{array}$ & 1,0 \\
\hline Sempoyongan & Menghambat sistem syaraf pusat & 1,0 \\
\hline Kehilangan refleks berdiri & Menghambat sistem syaraf pusat & 1,0 \\
\hline Kelumpuhan kaki & $\begin{array}{l}\text { Menghambat sistem syaraf pusat, relaksasi } \\
\text { otot }\end{array}$ & 1,0 \\
\hline $\begin{array}{l}\text { Pengecilan ukuran pupil } \\
\text { mata }\end{array}$ & $\begin{array}{l}\text { Parasimpatomimetik, Simpatolitik, } \\
\text { Menghambat sistem syaraf pusat }\end{array}$ & 1,5 \\
\hline Ekor mengangkat & Analgesik & 0,5 \\
\hline Lumpuh & Menghambat sistem syaraf pusat & 1,0 \\
\hline $\begin{array}{l}\text { Penurunan rasa ingin } \\
\text { tahu }\end{array}$ & $\begin{array}{l}\text { Menghambat sistem syaraf pusat, relaksasi } \\
\text { otot }\end{array}$ & 1,0 \\
\hline Tes hafner positif & $\begin{array}{l}\text { Menghambat sistem syaraf pusat, } \\
\text { Analgesik, relaksasi otot }\end{array}$ & 1,0 \\
\hline $\begin{array}{l}\text { Kehilangan daya } \\
\text { cengkram }\end{array}$ & $\begin{array}{l}\text { Menghambat sistem syaraf pusat, relaksasi } \\
\text { otot }\end{array}$ & 1,5 \\
\hline
\end{tabular}

Hubungan antara gejala keracunan akibat pemberian ekstrak kasar B. asiatica dengan perkiraan efek faali pada mencit (menurut Wagner \& Wolff) tertera pada Tabel 2. Dari 
hasil kategori yang diperlihatkan pada daftar nilai efek utama ekstrak metanol biji B. asiatica terhadap perilaku mencit, maka urutan efek utama ekstrak metanol biji $B$. asiatica dapat disusun seperti yang tertulis pada Tabel 3.

Tabel 3. Pengaruh ekstrak metanol biji B. asiatica terhadap efek faali pada mencit berdasarkan penilaian menurut Wagner dan Wolff dari yang tertinggi sampai yang terendah

\begin{tabular}{clc}
\hline $\begin{array}{c}\text { No } \\
\text { Urut }\end{array}$ & \multicolumn{1}{c}{ Perkiraan efek faali pada mencit } & Nilai \\
\hline 1 & Menghambat sistem syaraf pusat & 10 \\
2 & Relaksasi otot & 5,5 \\
3 & Simpatolitik & 2,5 \\
4 & Analgesik & 1,5 \\
5 & Parasimpatomimetik & 1,5 \\
\hline
\end{tabular}

Keterangan : Dari hasil pengamatan Pengaruh crude ekstrak biji B.asiatica terhadap perilaku mencit putih (M.musculus) yang diperlihatkan pada Tabel 3, dapat diperkirakan bahwa ekstrak kasar $B$. asiatica secara dominan dapat menghambat sistem syaraf pusat pada mencit.

\section{Pengaruh crude ekstrak biji B. asiatica terhadap produksi feses harian mencit putih}

Hasil pengamatan selama 5 hari dengan

4 kali ulangan pada "pengaruh pemberian ekstrak metanol biji B.asiatica (crude extrac) terhadap produksi feses harian diperoleh data rata rata produksi feses harian sebagai berikut (Tabel 4) :

Tabel 4. Rata-rata produksi feses harian pada mencit setelah diberi perlakuan ekstrak metanol biji $B$. asiatica dengan dosis yang berbeda

\begin{tabular}{cccccc}
\hline \multirow{2}{*}{ Perlakuan (dosis) } & \multicolumn{5}{c}{ Rata-rata produksi feses per hari dalam g $(\mathrm{x} \pm \mathrm{SB})$} \\
\cline { 2 - 6 } & Hari 1 & Hari 2 & Hari 3 & Hari 4 & Hari 5 \\
\hline $\mathrm{LD}_{75}(3714,6 \mathrm{ppm})$ & 0,02 & 0,03 & 0,01 & 0,04 & 0,05 \\
$\mathrm{LD}_{50}(1514,14 \mathrm{ppm})$ & $0,02 \pm 0,01$ & $0,05 \pm 0,01$ & $0,07 \pm 0,01$ & $0,08 \pm 0,04$ & $0,18 \pm 0,02$ \\
$\mathrm{LLD}_{25}(616,96 \mathrm{ppm})$ & $0,09 \pm 0,03$ & $0,07 \pm 0,04$ & $0,11 \pm 0.03$ & $0,14 \pm 0,05$ & $0,17 \pm 0,03$ \\
Kontrol & $0,32 \pm$ & $0,35 \pm 0,1$ & $0,29 \pm 0.09$ & $0,36 \pm 0,14$ & $0,40 \pm 0,08$ \\
\hline
\end{tabular}

Keterangan $: \mathrm{x}=$ rata-rata produksi feses mencit dalam g per hari

$\mathrm{SB}=$ Simpangan baku

$\mathrm{N}=$ Jumlah mencit yang masih hidup setelah perlakuan

Hasil pengamatan menunjukkan bahwa pemberian dosis ekstrak metanol biji $B$. asiatica berpengaruh terhadap laju produksi feses mencit. Jumlah produksi feses harian tertinggi diperoleh pada perlakuan kontrol, semakin tinggi pemberian dosis crude extrak maka semakin rendah produksi feses hariannya.

Hal ini didasarkan pada persamaan anggaran energy (Natawigena \& Soedigdo, 1998) bahwa C = D + F atau energi masukan makanan (konsumsi $=\mathrm{C}$ ) sebagian akan menjadi energi makanan yang dicerna 
(digestible energi $=\mathrm{D}$ ) dan sebagian lagi menjadi energi yang terkandung dalam buangan (feses $=F$ ).

Menurunnya produksi feses harian mencit diduga karena jenis racun dari $B$. asiatica yang bersifat racun perut mengakibatkan tikus mengalami gangguan percernaan, selain itu diduga pula karena $B$. asiatica bersifat antifeedant maka mencit pun mengalami penurunan nafsu makan yang mengakibatkan jumlah produksi feses mengalami penurunan. Bentuk feses tidak normal, sedikit lembek dan cenderung berwarna hitam keabu-abuan dengan ukuran yang lebih kecil dari biasanya.
Pengaruh crude ekstrak biji B. asiatica
terhadap produksi harian urin mencit
Hasil pengamatan mengenai efek pemberian dosis ekstrak metanol biji $B$. asiatica terhadap laju produksi harian urin pada mencit dapat dilihat pada Tabel 5 . Berdasarkan pengamatan tersebut, diperoleh data rata-rata laju pertambahan produksi urin harian dari mencit pada setiap perlakuan. Rata-rata laju produksi harian urin pada kontrol pada 5 hari pengamatan adalah 1,63 $\mathrm{ml} ; 0,87 \mathrm{ml} ; 1,5 \mathrm{ml} ; 1,5 \mathrm{ml}$ dan 1 $\mathrm{ml}$. Sedangkan pada perlakuan dengan dosis tertinggi $(3.714,6 \mathrm{ppm})$ memproduksi urin harian pada 5 hari pengamatan adalah $4 \mathrm{ml}$; $3 \mathrm{ml} ; 5 \mathrm{ml} ; 4 \mathrm{ml}$ dan $4 \mathrm{ml}$.

Tabel 5. Rata-rata produksi urin harian pada mencit setelah diberi perlakuan ekstrak metanol biji $B$. asiatica dengan dosis yang berbeda

\begin{tabular}{cccccc}
\hline \multirow{2}{*}{ Perlakuan (dosis) } & \multicolumn{5}{c}{ Rata-rata produksi urin perhari (x $\pm \mathrm{SB})$} \\
\cline { 2 - 6 } & Hari 1 & Hari 2 & Hari 3 & Hari 4 & Hari 5 \\
\hline $\mathrm{LD}_{75}(3714,6 \mathrm{ppm})$ & 4 & 3 & 5 & 4 & 4 \\
$\mathrm{LD}_{50}(1514,14 \mathrm{ppm})$ & $3,50 \pm 0,70$ & $4,50 \pm 0,70$ & 5 & $3,5 \pm 0,70$ & 3 \\
$\mathrm{LD}_{25}(616,96 \mathrm{ppm})$ & $2,33 \pm 0,58$ & $3,67 \pm 0,58$ & $3,00 \pm 1$ & $2,17 \pm 0,29$ & $2,67 \pm 0,58$ \\
Kontrol & $1,63 \pm 0,48$ & $0,87 \pm 0,48$ & $1,50 \pm 0,58$ & $1,5 \pm 0,58$ & $1 \pm 0,40$ \\
\hline
\end{tabular}

Keterangan $: \mathrm{x}$ = rata-rata produksi urin mencit dalam mililiter (hari)

$\mathrm{SB}=$ Simpangan baku

$\mathrm{N}$ = Jumlah mencit yang masih hidup setelah perlakuan

Berdasarkan Tabel 5 antara produksi urin dengan besarnya dosis ekstrak metanol biji B. asiatica yang diberikan menunjukkan hubungan yang berbanding lurus, semakin tinggi dosis ekstrak metanol biji B. asiatica yang diberikan semakin tinggi pula produksi urin harian mencit.

Berdasarkan hasil percobaan menunjukkan adanya indikasi yang mengakibatkan mencit memproduksi urin yang berlebih. Hal ini dikarenakan terganggunya sistem saraf pusat terutama pada susunan saraf parasimpatik yang diakibatkan pemberian ekstrak metanol biji B. asiatica pada mencit. Hal ini sejalan dengan pernyataan Fry et al. (2010) bahwa kerusakan pada saraf yang mengatur fungsi kandung kemih dapat memicu seringnya buang air kecil. Selain itu terjadi perubahan warna dari urin yang diproduksi oleh mencit. Semakin tinggi dosisnya semakin pekat pula warna urinnya. 
Pengaruh crude ekstrak biji B.asiatica terhadap pertambahan berat badan mencit

Berdasarkan hasil pengamatan mengenai efek pemberian dosis crude ekstrak metanol biji B. asiatica terhadap mencit, diperoleh data pertambahan berat badan mencit setiap hari pada setiap perlakuan seperti yang disajikan pada Tabel 6 . Rata-rata berat badan mencit pada awal penelitian adalah 26 g. Rata-rata pertambahan berat badan pada mencit yang tidak mendapat perlakuan (kontrol) masing-masing perlakuan selama 5 hari pengamatan adalah $2,25 \mathrm{~g} ; 1,76 \mathrm{~g} ; 2,245 \mathrm{~g} ; 1,89 \mathrm{~g}$ dan 1,53 g. Sedangkan pada perlakuan dengan dosis tertinggi (3714,6 ppm) pertambahan berat perharinya selama 5 hari pengamatan adalah 0,09 g; 0,21 g; 0,29 g; 0,42 g dan $0,39 \mathrm{~g}$ dengan jumlah mencit yang tersisa adalah 1 ekor.

Tabel 6. Rata-rata pertambahan berat berat badan pada tikus setelah diberi perlakuan ekstrak metanol biji $B$. asiatica dengan dosis yang berbeda

\begin{tabular}{|c|c|c|c|c|c|c|}
\hline \multirow{2}{*}{ Perlakuan (dosis) } & \multicolumn{5}{|c|}{ Rata-rata pertambahan berat berat badan mencit perhari $(x \pm S B)$} & \multirow[t]{2}{*}{$\mathrm{N}$} \\
\hline & Hari 1 & Hari 2 & Hari 3 & Hari 4 & Hari 5 & \\
\hline $\mathrm{LD}_{75}(3714,6 \mathrm{ppm})$ & 0,09 & 0,21 & 0,29 & 0,46 & 0,39 & 1 \\
\hline$-D_{50}(1514,14 \mathrm{ppm})$ & $0,14 \pm 0,30$ & $0,24 \pm 0,57$ & $0,29 \pm 0,67$ & $0,42 \pm 0,19$ & $0,38 \pm 0,78$ & 2 \\
\hline $\mathrm{LD}_{25}(616,96 \mathrm{ppm})$ & $0,26 \pm 0,55$ & $0,50 \pm 0,99$ & $0,54 \pm 0,61$ & $0,60 \pm 0,74$ & $0,99 \pm 0,49$ & 3 \\
\hline Kontrol & $2,25 \pm 1,30$ & $1,76 \pm 0,74$ & $2,45 \pm 0,89$ & $1,89 \pm 0,84$ & $1,53 \pm 0,70$ & 4 \\
\hline
\end{tabular}

Keterangan $: \mathrm{x}=$ rata-rata pertambahan berat badan mencit gram (hari)

$\mathrm{SB}=$ Simpangan baku

$\mathrm{N}$ = Jumlah mencit yang masih hidup setelah perlakuan

Berdasarkan Tabel 6 antara pertambahan berat badan mencit dengan besarnya dosis ekstrak metanol biji $B$. asiatica yang diberikan menunjukkan hubungan yang berbanding terbalik. Semakin tinggi dosis ekstrak metanol biji $B$. asiatica yang diberikan semakin menurun pula pertambahan berat badan harian mencit.

Menurut Dono et al. (2012) B. asiatica memiliki aktivitas antifeedant. Hasil percobaan ini mendukung indikasi bahwa ekstrak metanol $B$. asiatica mempunyai efek menghambat aktivitas makan dari mencit. Dengan demikian dapat dimengerti bahwa berkurangnya konsumsi makanan akan berpengaruh juga terhadap perubahan berat badan mencit. Hal ini sesuai dengan persamaan anggaran energi (Natawigena \& Soedigdo, 1998) yaitu bahwa energi masukan makanan ( C) akan dialokasikan ke produksi materi organik bagian dari tubuh harian ( $P$ ), energi yang digunakan untuk respirasi ( $B$ ), serta energi yang terdapat dalam buangan feses ( $F$ ) dan urin( $U$ ).

Pengaruh crude ekstrak B. asiatica terhadap organ detoksifikasi mencit

Pada pengamatan kali ini didapatkan beberapa indikasi pengaruh pemberian ekstrak $B$. asiatica terhadap organ detoksifikasi. Organ yang sangat berpengaruh dalam detoksifikasi mencit adalah hati, namun tidak menutup 
kemungkinan organ lain seperti ginjal, paruparu, empedu serta testis dari mencit dapat berperan dalam detoksifikasi racun ekstrak metanol biji B. asiatica. Perbedaan yang paling mencolok adalah pada warna organ hati yang terdapat pada mencit yang diberi perlakuan ekstrak metanol biji B. asiatica lebih hitam (gelap) dibandingkan dengan warna organ hati pada mencit yang tidak diberi perlakuan (kontrol).

Selain itu terdapat juga indikasi gangguan pada organ detoksifikasi lainnya yaitu ginjal. Hal ini terbukti dari produksi urin yang berlebih pada mencit. Diduga karena efek dari ekstrak metanol biji $B$. asiatica berpengaruh terhadap kinerja ginjal sehingga urin yang diproduksi oleh mencit terus bertambah berbanding lurus dengan dosis ekstrak metanol biji $B$. asiatica yang diberikan.

Pengaruh masing-masing perlakuan dapat mengindikasikan bahwa ekstrak metanol biji $B$. asiatica berpengaruh terhadap organ detoksifikasi pada mencit. Hal ini sesuai dengan pernyataan bahwa organ detoksifikasi (hati) dan eksresi (ginjal) adalah merupakan target organ dari bahan yang bersifat toksik (Köttgen et al., 2010) dan (Kowdley, 2012). Berbagai macam enzim metabolisme yang terdapat di dalam hati yang kandungannya tertentu dan tidak berfluktuasi terjadi pada makhluk hidup sehat, tetapi bila terjadi kerusakan sel pada hati maka enzim-enzim tersebut dapat mengakibatkan warna hati menjadi gelap karena enzim seperti SGPT, SGOT, alkalin fosfatase akan meningkat konsentrasinya (Numinha, 2013). Apabila organ ginjal rusak maka dapat mempengaruhi fungsinya sebagai penyaringan pembuangan elektrolit tubuh dan menjaga keseimbangan cairan dan zat kimia tubuh seperti sodium dan kalium di dalam darah atau produksi urin
(Warianto, 2013). Sedangkan perubahan komposisi dan konsistensi produksi urin serta kliren kreatinin sering juga digunakan sebagai indikator kerusakan pada organ ginjal (Ramirez-Sandoval \& Madero, 2018).

\section{SIMPULAN}

1. Ekstrak biji B. asiatica bersifat toksik terhadap mencit putih (Mus musculus) dengan nilai $\mathrm{LD}_{50}$ (2 jam) ; $2022 \mathrm{ppm}$ atau $0,2022 \%$ dan digolongkan ke dalam skala toksisitas 3 yaitu senyawa dengan toksisitas sedang. Ekstrak biji $B$. asiatica mempengaruhi sistem syaraf pusat mencit putih, meningkatkan produksi urin, menurunkan laju konsumsi dan produksi feses, serta menurunkan pertumbuhan bobot mencit.

2. Ekstrak biji B. asiatica berpotensi dikembangkan sebagai rodentisida nabati untuk pengendalian tikus yang merupakan hama pada berbagai komoditas pertanian.

\section{DAFTAR PUSTAKA}

Dono, D., Natawigena, W. D., \& Majid, M. G. (2012). Bioactivity of methanolic seed extract of Barringtonia asiatica L. (Kurz) (Lecythidaceae) on biological characters of Spodoptera litura (Fabricius) (Lepidoptera: Noctuidae). International Research Journal of Agricultural Science and Soil Science, 2(11), 469-475.

Febritami, G., Usiati, N., \& Dono, D. (2018). Toxicity of four kind plant extracts (Ageratum conyzoides L., Barringtonia asiatica (L.) Kurz., Melia azedarach L., Tephrosia vogelii Hook F.) against brown planthopper (Nilaparvata lugens STAL.). Jurnal Cropsaver. 
Finney, D. J. (1974). Statistics for biologists. Nature.https://doi.org/10.1038/24830 $8 \mathrm{a} 0$

Fry, C. H., Meng, E., \& Young, J. S. (2010). The physiological function of lower urinary tract smooth muscle. Autonomic Neuroscience: Basic and Clinical.https://doi.org/10.1016/j.autn eu.2009.10.006

Govindam, S., Kuchi, M., Balekari, U., \& Rani, G. S. (2011). Screening of wound healing effect of bark of Barringtonia asiatica. International Journal of Pharmacology Research.

Kardinan, A., Penelitian, B., Obat, T., \& Aromatik, D. (2011). Penggunaan pestisida nabati sebagai kearifan lokal dalam pengendalian hama tanaman menuju sistem pertanian organik. Agustus Pengembangan Inovasi Pertanian.

Komansilan, A., \& Suriani, N. W. (2016). Effectiveness of seed extract hutun (Barringtonia asiatica KURZ), on LARVA aedes aegypti vector disease dengue fever. International Journal of ChemTech Research.

Köttgen, A., Pattaro, C., Böger, C. A., Fuchsberger, C., Olden, M., Glazer, N. L., Fox, C. S. (2010). New loci associated with kidney function and chronic kidney disease. Nature Genetics.https://doi.org/10.1038/ng.5 68

Kowdley, K. V. (2012). Liver function tests and interpretation. In Geriatric Gastroenterology.https://doi.org/10.1 007/978-1-4419-1623-5_37

Montes De Oca, D. P., Lovera, R., \& Cavia, R. (2017). Where do Norway rats live? Movement patterns and habitat selection in livestock farms in Argentina. Wildlife Research.
https://doi.org/10.1071/WR16219

Natawigena, W. D., \& Soedigdo., S. (1998). Racun Gadung (Dioscorea hispida dennst) Isolasi, Struktur, Mekanisme Kerja, Antidotum Serta Penjajagan Sebagai Rodentisida. Laporan Penelitian Hibah Bersaing V Perguruan Tinggi.

Numinha. (2013). Gambaran Aktifitas Enzim SGOT dan SGPT Pada Penderita Demam Berdarah Dengue di RSUD Dr. Hi. Abdul Moeloek Hospital Bandar Lampung. Jurnal Analis Kesehatan.

Ramirez-Sandoval, J. C., \& Madero, M. (2018). Treatment of Hyperuricemia in Chronic Kidney Disease. In Contributions to Nephrology. https://doi.org/10.1159/000484288

Ravikumar, T., Nagesh-Ram, Dam-Roy, S., Krishnan, P., Grinson-George, Sankaran, M., \& Sachithanandam, V. (2015). Traditional usages of ichthyotoxic plant Barringtonia asiatica (L.) Kurz. by the Nicobari tribes. Journal of Marine and Island Cultures. https://doi.org/10.1016/j.imic.2015.10 .001

Rumampuk, R. J., Pongoh, E. J., Tarigan, P., Herlt, A. J., \& Mander, L. N. (2010). A triterpene ester saponin from the seed of Barringtonia asiatica. Indonesian Journal of Chemistry. https://doi.org/10.1073/pnas.1016308 108

Warianto, C. (2013). Gagal Ginjal. Hubungan Pola Hidup Sedentarian Dengan Kejadian Obesitas Sentral Pada Pegawai Pemerintahan Di Kantor Bupati Kabupaten Jeneponto. 